
ISSN : 2615-1995, E-ISSN : 2615-0654

J. Madani., Vol. 2, No. 2, September 2019 (201 - 215)

(C)2018 Lembaga Kajian Demokrasi

MADANI

dan Pemberdayaan Masyarakat (LKD-PM)

\title{
Penerapan Discovery Learning Dengan Pendekatan Scientific Dalam Meningkatkan Kemampuan Pemahaman Konsep dan Kemampuan Penalaran Matematis serta Dampaknya Terhadap Self Regulated Learning Siswa SMP
}

\author{
Fitri Sabina \\ Fakultas Ekonomi, Universitas Pamulang \\ dosen02019@unpam.ac.id
}

\begin{abstract}
Abstrak
Penelitian ini bertujuan untuk menganalisis dan mendeskriptifkan secara kritis tentang implementasipenerapan discovery learning dengan pendekatan saintifik untuk meningkatkan kemampuan pemahaman konsep dan penalaran matematis serta melihat seberapa besar pengaruh pembelajaran ini terhadap self regulated learning siswa kelas VIII SMP.N. 2 Kab Cirebon. Sementara latar belakang penelitian ini berawal untuk meningkatkan kualitas pendidikan khususnya dalam pelajaran matematika karena pelajaran matematika pada hakikatnya berkaitan dan dipakai dalam kehidupan sehari-hari. Pembelajaran merupakan proses ilmiah, karna itu siswa dapat dengan aktif menemukan (discovery) suatu konsep atau prinsip pembelajaran, sehingga proses pembelajaran akan berpindah dari guru yang mendominasi pembelajaran menajdi siswa yang aktif. Metode penelitian yang digunakan dalam penelitian ini adalah metode campuran dengan tipe penyisipan, dengan sampel penelitian sebanyak 35 siswa. Penelitian ini menggunakan dua jenis analisis data: analisis data kualitatif, yang terdiri dari tes kemampuan pemahaman konsep dan tes penalaran matematis, kemudian analisis data kualitatif, berupa angket self regulated learning, observasi dan wawancara. Hasil penelitian menunjukkan terdapat peningkatan kemampuan pemahaman konsep dan penalaran matematis siswa yang diajarkan model pembelajaran discovery learning dengan pendekatan saintifik, terdapat hubungan peningkatan kemampuan pemahamn konsep dan penalaran matematis siswa pada kelas yang diajarkan model pembelajaran discovery learning dengan pendekatan saintifik, serta memberikan pengaruh peningkatan self regulated learning siswa.
\end{abstract}

Kata Kunci : Discovery Learning, Pendekatan Saintifik, Pemahaman Konsep, Penalaran Matematis, Self Regulated Learning

\begin{abstract}
This study aims to analyze and describe critically about the implementation of the application of learning findings by supporting science to improve understanding of concepts and mathematical penalties and see greater learning oriented to independent learning arranged by the eighth grade students of SMP.N. 2 Cirebon Regency. While the background of this research begins to improve the quality of education in mathematics because mathematics about its nature is related and used in everyday life. Learning is a scientific process, because students can actively find (discovery) a learning concept, so that the learning process will move from the teacher that encourages active learning into students. The research method used in this study is a mixed method with type of insertion, with a sample of 35 students. This study uses two types of data analysis: qualitative data analysis, which consists of the ability test to understand concepts and mathematical punishment tests, then analysis of qualitative data, consisting of self-study questionnaires, observation and interviews. The results showed about the development of understanding concepts and mathematical punishments of students discussing learning
\end{abstract}


discovery learning models using scientific, relating to the improvement of the ability to understand concepts and mathematical punishments of students in the class that encourage learning discovery learning models with scientific assistance, and provide self-regulated improvement assistance student learning.

\section{Keywords : Discovery Learning, Scientific Approach, Concept Understanding, Mathematical Reasoning, Self Regulated Learning}

\section{PENDAHULUAN}

\section{Latar Belakang}

Matematika merupakan salah satu mata pelajaran yang menjadi fokus pendidikan untuk membekali siswa memiliki kemampuan berpikir logis, kritis, sistematis, analitis, dan kreatif. Matematika juga berperan penting dalam berbagai disiplin ilmu lain serta memiliki peranan untuk mengembangkan pola pikir manusia. Oleh sebab itu siswa diharapkan dapat menguasai matematika, karena dengan menguasai matematika akan memudahkan memahami bidang ilmu lainnya.

Berdasarkan Permendiknas Nomor 22 Tahun 2006 tentang Standar Isi Mata Pelajaran Matematika, tujuan pembelajaran matematika antara lain agar siswa mampu: (1) Memahami konsep matematika, menjelaskan keterkaitan antarkonsep dan mengaplikasikan konsep atau algoritma, secara luwes, akurat, efisien, dan tepat, dalam pemecahan masalah, (2) Menggunakan penalaran pada pola dan sifat, melakukan manipulasi matematika dalam membuat generalisasi, menyusun bukti, atau menjelaskan gagasan dan pernyataan matematika, (3) Memecahkan masalah yang meliputi kemampuan memahami masalah, merancang model matematika, menyelesaikan model dan menafsirkan solusi yang diperoleh, (4) Mengomunikasikan gagasan dengan simbol, tabel, diagram, atau media lain untuk memperjelas keadaan atau masalah, dan (5) Memiliki sikap menghargai kegunaan matematika dalam kehidupan, yaitu memiliki rasa ingin tahu, perhatian, dan minat dalam mempelajari matematika, serta sikap ulet dan percaya diri dalam pemecahan masalah.

Untuk mencapai tujuan tersebut, tentunya terdapat proses kegiatan berpikir tingkat tinggi yang dialami oleh siswa. Proses kegiatan berpikir menurut Galloti (Matlin, 1994:379) meliputi tiga bagian, yaitu problem solving, logical reasoning, dan decision making. Gosev dan Safuanov (Dahlan, 2004) mengemukakan bahwa proses tersebut memberikan suatu gambaran bahwa kegiatan berpikir memerlukan pemahaman terhadap suatu permasalahan yang berhubungan dengan materi yang sedang dipikirkan, kemampuan bernalar, kemampuan intelektual, imajinasi, dan fleksibilitas dari pikiran yang merentang ke dalam hasil pemikiran itu sendiri.

Banyak faktor yang menyebabkan rendahnya hasil belajar matematika siswa. Antara lain yaitu dari matematika sendiri yang berperan sebagai produk dan proses, artinya siswa harus memahami konsep, prinsip, hukum, aturan, kesimpulan yang diperoleh dan bagaimana cara memperoleh semua itu, faktor guru, orang tua, siswa, sekolah dan kurikulum.

Lebih lanjut guru memaparkan bahwa siswa masih kesulitan untuk memahami masalah konseptual. Siswa sebagai subjek belajar kurang dilibatkan dalam menemukan konsep-konsep pelajaran yang harus dikuasainya. Hal ini akan membatasi kemampuan pemahaman dan kemampuan penalaran matematis siswa karena siswa kurang diberi kesempatan untuk mengeksplorasikan ide-idenya, dan akan berdampak terhadap self regulated learning siswa dalam pembelajaran matematika yang sulit terbentuk.

Self regulated learning itu sendiri adalah proses belajar siswa yang aktif secara individu untuk mencapai tujuan akademik dengan cara pengontrolan perilaku, memotivasi diri sendiri, dan mampu menggunakan pengetahuan belajarnya dalam menyelesaikan masalah.

Sejalan dengan pergantian kurikulum 2013, istilah pendekatan ilmiah atau scientific approach pada pelaksanaan pembelajaran menjadi bahan pembahasan yang menarik perhatian bagi para pendidik. Pendekatan saintifik adalah proses 
pembelajaran yang dirancang agar siswa aktif mengkontruksi konsep, hukum, atau prinsip yang ditemukan melalui tahap mengidentifikasi atau menemukan masalah, merumuskan masalah, merumuskan hipotesis, mengumpulkan data dengan berbagai teknik, menganalisis data, menarik kesimpulan dan mengkomunikasikan konsep, hukum atau prinsip yang ditemukan. Hal ini sejalan dengan Permendikbud no 65 (2013) disebutkan bahwa untuk memperkuat pendekatan ilmiah (scientific), perlu diterapkan pembelajaran berbasis penelitian diantaranya adalah discovery learning. Metode discovery learning merupakan penemuan yang dilakukan oleh peserta didik itu sendiri yang merupakan hal yang baru pada dirinya sendiri walaupun sudah diketahui oleh orang. Hal-hal yang baru tersebut dapat berupa konsep, teorema, rumus, pola, aturan, dan sejenisnya, untuk dapat menemukan mereka harus melakukan terkaan, dugaan, coba-coba, dan usaha lainnya dengan menggunakan pengetahuan siapnya. Dengan demikian, model discovery learning sangat relevan dengan pendekatan saintifik yang terdiri dari mengamati, menanya, mencoba, menalar dan mengkomunikasikan yang direkomendasi oleh kurikulum 2013 karena dapat meningkatkan kemampuan pemahaman konsep dan kemampuan penalaran siswa.

Proses pembelajaran kurikulum 2013 berbeda dengan proses pembelajaran kurikulum sebelumnya yaitu kegiatan inti masih berpusat pada guru. Proses pembelajaran kurikulum 2013, menuntut siswa lebih aktif dan kreatif dalam menerima materi. Mencermati hal tersebut, sudah seharusnya diadakan inovasi terhadap proses pembelajaran guna tercapainya tujuan pembelajaran matematika. Proses pembelajaran yang efektif dan menarik, agar membuat siswa dapat menemukan dan mengembangkan konsep yang dipelajari, menggunakan pemahaman konsep dan penalaran serta mengarahkan siswa untuk belajar dengan mandiri, bukan pembelajaran biasa seperti ceramah yang dirasakan kurang mendorong minat belajar dan rasa penasaran siswa pada pelajaran matematika. Model pembelajaran tersebut dinamakan model pembelajaran discovery learning dengan pendekatan saintifik

\section{Rumusan Masalah}

1. Apakah peningkatan kemampuan pemahaman konsep matematis siswa SMP yang mengikuti pembelajaran discovery learning dengan pendekatan saintifik lebih baik daripada siswa yang mengikuti pembelajaran konvensional?

2. Apakah peningkatan kemampuan penalaran matematis siswa SMP yang mengikuti pembelajaran discovery learning dengan pendekatan saintifik lebih baik daripada siswa yang mengikuti pembelajaran konvensional?

3. Apakah self regulated learning siswa yang mengikuti pembelajaran discovery learning dengan pendekatan lebih baik dari pada siswa yang belajar dengan menggunakan pembelajaran konvensional?

4. Bagaimana self regulated learning siswa setelah pembelajaran matematika melalui model discovery learning dengan pendekatan saintifik?

5. Apakah terdapat hubungan antara peningkatan kemampuan pemahaman konsep dan kemampuan penalaran matematis yang menggunakan pembelajaran discovery learning dengan pendekatan saintifik?

6. Apakah terdapat pengaruh peningkatan kemampuan pemahaman kosep dan peningkatan kemampuan penalaran matematis terhadap self regulated learning pada kelas yang menggunakan pembelajaran discovery learning dengan pendekatan saintifik.

\section{Kajian Pustaka}

\section{Kemampuan Pemahaman Konsep}

Pemahaman konsep pada pembelajaran melalui penelitian ini dibatasi pada pemahaman instrumental dan pemahaman relasional dari Skemp, dengan mengacu pada indikator Kilpatrick dan Findell, yaitu: a) kemampuan mengklasifikasikan objek-objek berdasarkan dipenuhi atau tidaknya persyaratan yang membentuk konsep tersebut, b) kemampuan menerapkan konsep secara algoritma, kemampuan memberikan contoh dan counter example dari konsep yang telah dipelajari, c) kemampuan menyajikan konsep dalam berbagai macam bentuk representasi matematika, 
d) dan kemampuan mengaitkan berbagai konsep (internal dan eksternal matematika).

\section{Kemampuan Penalaran Matematis}

Penalaran berasal dari istilah bahasa Inggris yaitu reasoning dimana menurut Shuter and Pierce (Sumarmo, 1987) yang berarti proses berpikir untuk menarik kesimpulan logis berdasarkan fakta dan sumber yang relevan. Aspek ini merupakan tahapan berpikir matematik yang paling tinggi sehingga mencakup kapasitas untuk berpikir secara logik dan sistematik. Berdasarkan pemaparan tersebut, maka indikator dalam penelitian ini adalah kemampuan: a) Kemampuan mengajukan dugaan, b) Kemampuan memanipulasi matematika, c) Kemampuan menarik kesimpulan, menyusun bukti, memberikan alasan atau bukti terhadap kebenaran solusi, d) Kemampuan memeriksa kesahihan suatu argumen, e) Kemampuan menemukan pola atau sifat dari gejala matematis untuk membuat generalisasi.

\section{Discovery Learning}

Metode discovery learning (penemuan) adalah metode mengajar yang mengatur pengajaran sedemikian rupa sehingga anak memperoleh pengetahuan yang sebelumnya belum diketahui, pengetahuan yang didapat tidak hanya di dapat dari pemberitahuan, sebagian atau seluruhnya ditemukan sendiri. Sebagaimana pendapat Bruner, bahwa: "Discovery Learning can be defined as the learning that takes place when the student is not presented with subject matter in the final form, but rather is required to organize it him self" (Lefancois dalam Emetembun, 1986:103, dalam Depdikbud, 2014). Yang menjadikan dasar ide Bruner ialah pendapat dari Piaget yang menyatakan bahwa anak harus berperan aktif dalam belajar di kelas.

Di dalam proses belajar, Bruner mementingkan partisipasi aktif dari tiap peserta didik, dan mengenal dengan baik adanya perbedaan kemampuan. Untuk menunjang proses belajar diperlukan lingkungan yang memfasilitasi rasa ingin tahu peserta didik pada tahap eksplorasi. Lingkungan ini dinamakan discovery learning environment, yaitu lingkungan dimana peserta didik dapat melakukan eksplorasi, penemuanpenemuan baru yang belum dikenal atau pengertian yang mirip dengan yang sudah diketahui. Lingkungan seperti ini bertujuan agar peserta didik dalam proses belajar dapat berjalan dengan baik dan lebih kreatif.

Untuk memfasilitasi proses belajar yang baik dan kreatif harus berdasarkan pada manipulasi bahan pelajaran sesuai dengan tingkat perkembangan kognitif peserta didik. Manipulasi bahan pelajaran bertujuan untuk memfasilitasi kemampuan peserta didik dalam berpikir (merepresentasikan apa yang dipahami) sesuai dengan tingkat perkembangannya. Menurut Bruner perkembangan kognitif seseorang terjadi melalui tiga tahap yang ditentukan oleh bagaimana cara lingkungan, yaitu: enactiv, iconic, dan symbolic. Tahap enactiv, seseorang melakukan aktivitasaktivitas dalam upaya untuk memahami lingkungan sekitarnya, artinya, dalam memahami dunia sekitarnya anak menggunakan pengetahuan motorik, misalnya melalui gigitan, sentuhan, pegangan, dan sebagainya. Tahap iconic, seseorang memahami objek-objek atau dunianya melalui gambar-gambar dan visualisasi verbal. Maksudnya, dalam memahami dunia sekitarnya anak belajar melalui bentuk perumpamaan (tampil) dan perbandingan (komparasi). Tahap symbolic, seseorang telah mampu memiliki ide-ide atau gagasan-gagasan abstrak yang sangat dipengaruhi oleh kemampuannya dalam berbahasa dan logika. Dalam memahami dunia sekitarnya anak belajar melalui simbol-simbol bahasa, logika, matematika, dan sebagainya.

\section{Pendekatan Saintifik}

Pedekatan saintifik tidak hanya memandang hasil belajar sebagai muara akhir, namun proses pembelajaran dipandang sangat penting. Oleh karena itu pembelajaran saintifik menekankan pada keterampilan proses. Model pembelajaran berbasis peningkatan keterampilan proses sains adalah model pembelajaran yang mengintegrasikan keterampilan proses sains ke dalam sistem penyajian materi secara terpadu (Beyer, 1991). Pendekatan ini menekankan pada proses 
pencarian pengetahuan daripada transfer pengetahuan, peserta didik dipandang sebagai subjek belajar yang perlu dilibatkan secara aktif dalam proses pembelajaran, guru hanyalah seorang fasilitator yang membimbing dan mengkoordinasikan kegiatan belajar.

Ini dapat dilihat dari karakteristik pembelajaran dengan pendekatan saintifik yaitu berpusat pada siswa, melibatkan keterampilan proses sains dalam mengkonstruksi konsep, hukum atau prinsip melibatkan proses-proses kognitif yang potensial dalam merangsang perkembangan intelek, khususnya keterampilan berpikir tingkat tinggi siswa dapat mengembangkan karakter siswa.

Pendekatan ini juga tercakup penemuan makna (meanings), organisasi, dan struktur dari ide atau gagasan, sehingga secara bertahap siswa belajar bagaimana mengorganisasikan dan melakukan penelitian. Pembelajaran berbasis keterampilan proses sains menekankan pada kemampuan peserta didik dalam menemukan sendiri (discover) pengetahuan yang didasarkan atas pengalaman belajar, hukum-hukum, prinsip-prinsip dan generalisasi, sehingga lebih memberikan kesempatan bagi berkembangnya keterampilan berpirkir tingkat tinggi (Houston, 1988).

\section{Self Regulated Learning}

Self regulated learning adalah suatu upaya siswa aktif untuk mengembangkan pengetahuan yang didapat dengan menggunakan cara-cara yang relevan dan tidak terbatas hanya pada materi pelajaran yang didapat siswa dari lingkungan sekolah. Strategi self regulated learning yang dikemukakan oleh Zimmerman \& schunk (1989) menemukan bahwa para siswa menggunakan 14 tipe self regulated learning. Berikut adalah strategistrategi self regulated learning: (1) Self Evaluating; (2) organizing and Transforming; (3) Goal-setting and Planning; (4)Seeking Information; (5) Keeping Records and Monitoring; (6) Environmental Structuring; (7) SelfConsequanting; (8) Rehearsing and Memorizing; (9) seeking social assistance from peers; (10) seeking social assistance from teacher; (11) seeking social assistance from adult; (12) Reviewing Records from note; (13) Reviewing Records from textbook; (14) others.
Menurut Gagne dan Marzano (dalam Fitria, 2009), self regulated learning dilandasi oleh paham konstruktivisme dimana pembelajaran dirancang dan dikelola sedemikian rupa sehingga mampu mendorong siswa untuk mengorganisasi pengalamannya sendiri menjadi suatu pengetahuan baru yang bermakna. Pada penelitian ini di rumuskan 7 indikator self regulated learning peserta didik dalam matematika yang memuat: 1) menunjukan inisiatif belajar, 2) mendiagnosis kebutuhan belajar, 3) menetapkan target belajar, 4) memanfaatkan dan mencari sumber belajar, 5) memilih strategi belajar, 6) mengevaluasi proses belajar dan pencapaian tujuan belajar, 7) mengontrol diri.

\section{METODE}

Metode penelitian yang digunakan adalah metode campuran (mixed method) tipe penyisipan (embedeed desain) dengan desain penelitian yang digunakan adalah desaian penelitian kuasi eksperimen, dan pemilihan sample dilakukan secara purposive sampling, dimana subjek tidak dipilih secara acak. Kemudian untuk sampel dalam penelitian ini adalah siswa kelas VII SMP. Dari beberapa kelas yang ada, dipilih 1 kelas sebagai kelas eksperimen dan 1 kelas sebagai kelas kontrol. Sampel tersebut ditujukan untuk mendapat data kuantitatif, sedangkan untuk data kualitatif dipilih 5-10 orang siswa dari kelas eksperimen.

Instrumen dalam penenlitian ini berupa soal tes kemampuan pemahaman konsep dan kemampuan penalaran matematis, angket self regulated learning, lembar observasi, dan pedoman wawancara. Uji coba instrumen, dilakukan uji validitas, reliabilitas, indek kesukaran, serta daya pembeda. Pengujian statistik diolah dengan menggunakan perhitungan statistika dengan bantuan software SPSS 17.0 dan Microsoft Office Excell 2010, dengan tingkat signifikansi 5\%. Apabila data berdistribusi normal dan homogen, maka uji hipotesis penelitian akan menggunakan uji $\mathrm{t}$ independent sample test, sementara apabila data berdistribusi normal dan tidak homogen, maka uji hipotesis menggunakan uji t' independent 
sample test, sedangkan apabila data tidak berdistribusi normal, uji hipotesis dilakukan dengan menggunakan uji non parametrik Mann-Whitney $U$.

\section{Temuan}

\section{Kemampuan Pemahaman Konsep}

Data hasil kemampuan pemahaman konsep diperoleh dari jawaban pretest dan posttest. Kemudian peningkatan kemampuan pemahaman konsep matematis siswa melalui pembelajaran discovery learning dengan pendekatan saintifik dilihat dari data skor gain ternormalisasi melalui tes soal uraian tersebut antara kelas eksperimen dan kontrol masing-masing 35 sampel.

Perbandingan analisis skor pretest, posttest kemampuan pemahaman konsep menunjukan bahwa rataan pretest kelas kontrol yaitu 5.97 lebih tinggi dari kelas eksperimen dengan rata-rata 5.74 sebelum diberikan perlakuan, sedangkan untuk rataan posttest kelas eksperimen yang memperoleh pembelajaran discovery learning dengan pendekatan saintifik menunjukan hasil 16.77 yang lebih tinggi dibandingkan kelas kontrol yang memperoleh pembelajaran konvensional dengan rata-rata 15.66. Dari data terlihat terjadi peningkatan skor kemampuan pemahaman konsep matematis siswa setelah pembelajaran dilaksanakan. Untuk melihat kemampuan awal pemahaman konsep siswa pada kelas eksperimen dan kontrol selanjutnya dilakukan uji Mann Whitney yang kemudian didapat hasil bahwa tidak terdapat perbedaan rata-rata data pretest kemampuan pemahaman konsep yang signifikan antara siswa kelas eksperimen dan kelas kontrol.

Setelah itu diberi perlakuan berbeda, untuk kelas eksperimen pembelajaran discovery learning dengan pendekatan saintifik, sedangkan pada kelas kontrol pembelajaran dilakukan dengan pembelajaran konvensional, pada akhir pembelajaran seluruh siswa diberi posttest dengan tujuan untuk mengetahui kemampuan pemahaman konsep siswa setelah proses pembelajaran berlangsung. Untuk analisis data n-gain dilakukan uji independent sample karena diasumsikan kedua data berdistribusi normal dan homogen. Maka diperoleh nilai signifikansi pada uji independen sampel untuk skor N-Gain kemampuan pemahaman konsep siswa adalah 0,0005 , lebih kecil dari $\alpha=0,05$, maka $\mathrm{H}_{0}$ ditolak atau terdapat perbedaan rata-rata data $N$-Gain kemampuan pemahaman konsep yang signifikan antara siswa kelas ekperiment dan siswa kelas kontrol, dengan rata-rata $N$-Gain siswa kelas eksperimen lebih tinggi daripada kelas kontrol, hal tersebut berarti pada tingkat kepercayaan 95\%, peningkatan kemampuan pemahaman konsep matematis antara siswa yang mendapat pembelajaran discovery learning dengan pendekatan saintifik lebih baik dari siswa yang mendapat pembelajaran konvensional.

\section{Kemampuan Penalaran Matematis}

Didapat rata-rata skor pretest kemampuan penalaran siswa kelas eksperimen dan kelas kontrol berbeda, dengan rata-rata kelas kontrol 5.54 lebih besar daripada kelas eksperiment 5.20. Kemudian rataan skor $N$-Gain kelompok eksperimen dan kontrol menunjukan perbedaan, rataan kelas eksperimen 0.76 lebih besar dari kelas kontrol 0.68. Selanjutnya untuk melihat apakah perbedaan tersebut signifikan (dapat digeneralisasikan) atau tidak, dilakukan analisis statistik inferensial. untuk melihat kemampuan awal penalaran matematis siswa pada kelas eksperimen dan kontrol selanjutnya dilakukan uji Mann Whitney, ini dikarenakan salah satu data tidak berdistribusi normal. Didapat nilai signifikansi 2-tailed uji Mann Whitney data kemampuan penalaran matematis awal siswa adalah 0,502 lebih besar dari 0,05, maka $\mathrm{H}_{0}$ diterima. Dengan kata lain, tidak terdapat perbedaan rata-rata data pretest kemampuan penalaran matematis yang signifikan antara siswa kelas eksperimen dan kelas kontrol.

Setelah itu diberi perlakuan berbeda, untuk kelas eksperimen model pembelajaran discovery learning dengan pendekatan saintifik, sedangkan pada kelas kontrol pembelajaran dilakukan dengan pembelajaran konvensional, pada akhir pembelajaran seluruh siswa diberi posttest dengan tujuan untuk mengetahui peningkatan kemampuan penalaran matematis siswa. Untuk analisis data n-gain dilakukan uji 
independent sample karena diasumsikan kedua data berdistribusi normal dan homogen. Didapat nilai signifikansi pada uji independent sampel untuk skor $\mathrm{N}$-Gain kemampuan penalaran matematis siswa adalah 0,002 , lebih kecil dari $\alpha=0,05$, maka $\mathrm{H}_{0}$ ditolak atau terdapat perbedaan rata-rata data $\mathrm{N}$-Gain kemampuan penalaran matematis yang signifikan antara siswa kelas ekperimen dan siswa kelas kontrol, dengan ratarata $\mathrm{N}$-Gain siswa kelas eksperimen lebih tinggi daripada kelas kontrol, hal tersebut berarti pada tingkat kepercayaan 95\%, terdapat perbedaan peningkatan kemampuan penalaran matematis siswa yang mendapat pembelajaran discovery learning dengan pendekatan saintifik lebih baik dari siswa siswa yang mendapat pembelajaran konvensional.

\section{Self regulated Learning}

Berdasarkan analisis data didapat rataan skor self regulated learning siswa untuk kelas eksperimen adalah 107.6 lebih besar daripada kelas kontrol dengan rataan 92.57. Untuk mengetahui apakah self regulated learning siswa kelas eksperimen lebih baik dari kelas kontrol dilakukan uji rataan skor self regulated learning. Uji rataan ini dilakukan uji non parametrik Mann Whitney dengan taraf signifikan $\alpha=0.05$. Uji non parametrik Mann Whitney digunakan karena analisis skala self regulated learning menggunakan data ordinal. Hasil analisis uji mann whitney skor self regulated learning matematis Sig. (2-tailed) yaitu 0.001 lebih kecil dari $\alpha=0.05$, maka $\mathrm{H}_{0}$ ditolak, artinya secara signifikan rataan skor self regulated learning siswa eksperimen lebih baik dari siswa kelas kontrol dengan pembelajaran konvensional.

\section{Korelasi Antara Kemampuan}

\section{Pemahaman Konsep dan Penalaran Matematis}

Uji korelasi dilakukan untuk melihat apakah ada korelasi peningkatan antara kedua kemampuan setelah diberikan pembelajaran dengan menggunakan Discovery Learning dengan pendekatan saintifik. Pengolahan data dilakukan dengan uji person corellation dengan hasil signifikansi korelasi antara kemampuan pe- mahaman konsep dengan kemampuan penalaran matematis siswa berada pada nilai sig 0.000 lebih kecil dari $\alpha=0.05$, maka $\mathrm{H}_{0}$ di tolak. Hal ini berarti pada tingkat kepercayaan 95\%, data kemampuan pemahaman konsep dengan kemampuan penalaran matematis siswa memiliki hubungan. Untuk nilai korelasi person adalah positif 0.571 menunjukan kemampuan pemahaman konsep dan penalaran matematis berada dalam katagori sedang, sementara nilai positif mengidentifikasikan pola kedua kemampuan tersebut searah (semakin tinggi kemampuan pemahaman konsep maka semakin tinggi pula kemampuan penalaran matematis).

\section{Pengaruh Kemampuan Pemahaman Konsep dan Penalaran Matematis Terhadap Self Regulated Learning}

Pengujian hipotesis ini melakukan analisis hubungan kausal, yaitu melihat sejauh mana pengaruh kemampuan pemahaman konsep dan kemampuan penalaran matematis terhadap self regulated learning siswa yang menggunakan model pembelajaran discovery learning dengan pendekatan saintifik.

Berdasarkan analisis uji regresi linear berganda didapat bahwa nilai $\mathrm{R}$ sebesar 0.651 menunjukkan bahwa pengaruh antara kemampuan penalaran matematis siswa sebagai variable bebas terhadap self regulated learning sebagai terikat adalah kuat, karena nilai $\mathrm{R}$ diatas atau $<0,5$. Sementara nilai $\mathrm{R}^{2}$ (koefisien determinasi) sebesar 0.423 yang berarti $42,3 \%$ variasi dari self regulated learning dipengaruhi oleh kemampuan penalaran matematis. Adapun sisanya, yaitu $57.7 \%$ dipengaruhi oleh faktor lain yang tidak diteliti lebih lanjut.

Persamaam regresinya yaitu $\hat{Y}=\mathrm{a}+\mathrm{bX}_{1} ;+$ cX 2 sehingga $\hat{Y}=28.210+7.648 \mathrm{X}_{1}+71.789 \mathrm{X}_{2}$. Konstanta sebesar 28.210 artinya jika KPK $\left(\mathrm{X}_{1}\right)$ dan KPM $\left(\mathrm{X}_{2}\right)$ nilainya adalah 0 , maka nilai self regulated learning $\hat{Y}$ nilainya positif yaitu sebesar 28.210. Selanjutnya koefisien regresi KPK sebesar 7.648 dan koefisien regresi KPM sebesar 71.789. Hal ini berarti jika kemampuan pemahaman konsep meningkat, maka self regulated learning siswa akan mengalami peningkatan sebesar 7.648 
dan jika kemampuan penalaran matematis meningkat, maka self regulated learning siswa akan mengalami peningkatan sebesar 71.789. Koefisien bernilai positif artinya terjadi hubungan positif antara kemampuan pemahaman konsep dan kemampuan penalaran matematis siswa terhadap self regulated learning, semakin meningkat kedua kemampuan tersebut maka semakin baik self regulated learning.

Adapun hasil signifikansi sebesar 0.742 atau artinya sig $>0.05, \mathrm{H}_{0}$ diterima atau dengan kata lain kemampuan pemahaman konsep tidak berpengaruh terhadap self regulated learning siswa. Dan hasil signifikansi sebesar 0.001 atau artinya sig $<0.05, \mathrm{H}_{0}$ ditolak atau dengan kata lain kemampuan penalaran matematis berpengaruh terhadap self regulated learning siswa.

\section{Observasi}

Diantara observasi yang dilakukan dalam penelitian ini adalah mengamati aktivitas guru pada saat proses pembelajaran dikelas eksperimen yang bertujuan untuk mengetahui sejauh mana pelaksanaan pembelajaran discovery learning dengan pendekatan saintifik. Grafik aktivitas guru dalam pembelajaran discovery learning dengan pendekatan saintifik memperlihatkan gambaran secara keseluruhan aktivitas guru yang dalam hal ini adalah peneliti sendiri menerapkannya hampir berjalan dengan baik. Hal ini ditandai dengan peningkatan grafik. Aktifitas guru pada pertemuan pertama awal penelitian merupakan aktivitas terendah, dari hasil lembar observasi mencerminkan hasil yang tidak terlalu baik. Hal ini disebabkan karna guru baru pertama kali bertemu dengan siswa dan belum terbiasa menggunakan model pembelajaran discovery learning dengan pendekatan saintifik, sedangkan untuk pertemuan berikutnya terjadi peningkatan yang lebih baik.

Berdasarkan observasi aktivitas siswa selama penelitian berlangsung, diperoleh hasil pada setiap pertemuannya setiap indikator mengalami peningkatan dan ada juga yang mengalami penurunan.

\section{Wawancara}

Rata-rata sebagian besar hasil wawancara dapat disimpulkan bahwa siswa memiliki dampak self regulated learning yang positif pada pembelajaran matematika dengan model pembelajaran discovery learning dengan pendekatan saintifik, dikarenakan pembelajaran ini dapat memotivasi siswa serta merangsang siswa untuk belajar lebih aktif, kreatif, dan mandiri sehingga dengan sendirinya dapat meningkatkan kemampuan pemahaman konsep dan penalaran matematis siswa dan menjadikan siswa mandiri untuk menyelesaikan persoalan matematika.

Demikian pula hal ini tergambar dari setiap jawaban siswa dalam hasil wawancara, banyak siswa yang awalnya belum terbiasa dengan iklim dan struktur pembelajaran discovery learning dengan pendekatan saintifik ini sehingga membuat siswa kebingungan dalam menentukan konsep dan menyelesaikan permasalahan matematika, dan karena beberapa kendala juga yang dialami siswa seperti kurangnya sarana belajar (buku paket matematika), membuat guru harus lebih ekstra membimbing siswanya agar mampu mencapai tujuan pembelajaran. Namun seiringnya perjalanan waktu siswa nampak senang dan terbiasa dengan model pembelajaran discovery learning dengan pendekatan saintifik, siswa senang belajar kelompok untuk menyelesaikan permasalahan, mencoba berbagai soal untuk mengasah kemampuan matematika, dan mengerjakan semua tugas dengan baik dan benar.

\section{HASIL dan PEMBAHASAN}

Penerapan pembeajaran discovery learning dengan pendekatan saintifik telah dilaksanakan di kelas VIII SMP Negeri 2 Gunung Jati Kab. Cirebon pada pokok bahasan materi Persamaan Linear Satu Variabel. Dalam uraian kali ini akan membahas hasil dari penelitian mengenai pembelajaran discovery learning dengan pendekatan saintifik terhadap peningkatan kemampuan pemahaman konsep matematis dan penalaran matematis siswa, selanjutnya dilihat perbandingan self regulated learning siswa, serta dampak self regulated learning siswa setelah diberikan pembelajaran discovery 
learning dengan pendekatan saintifik. Selain itu dibahas juga korelasi antara kemampuan pemahaman konsep dan penalaran matematis siswa, kemudian pembahasan regrasi antara kemampuan pemahaman konsep, dan penalaran matematis terhadap self regulated learning siswa.

Pembahasan ini didasarkan pada data yang telah dianalisis dari hasil penelitian. Hasil dari analisis yang telah diuraikan merupakan jawaban dari rumusan masalah dan menelaah tercapai atau tidaknya tujuan dalam penelitian ini. Berikut akan diuraikan secara lengkap pembahasan hasil pengujian hipotesis dan interprestasinya.

\section{A. Kemampuan Pemahaman Konsep}

Dari hasil penelitian menunjukkan bahwa peningkatan kemampuan pemahaman konsep matematis siswa yang mendapat pembelajaran discovery learning dengan pendekatan saintifik lebih baik dari pada siswa yang mendapat pembelajaran konvensional. Hasil tersebut sesuai dengan penelitian yang pernah dilakukan oleh (Haqq, 2010)

Penelitian menunjukkan bahwa pada kelas pembelajaran discovery learning dengan pendekatan saintifik memperlihatkan penguasaan terhadap aspek kemampuan pemahaman konsep matematis, diantaranya menurut (Killpatrick dan Findel, 2001) mengemukakan beberapa indikator pemahaman konsep yang mencakup a) menyatakan ulang suatu konsep, b) kemampuan mengklasifikasikan objek-objek berdasarkan dipenuhi atau tidaknya persyaratan yang membentuk konsep tersebut, c) kemampuan menerapkan konsep secara algoritma, d) kemampuan memberikan contoh dan counter example dari konsep yang telah dipelajari, e) kemampuan menyajikan konsep dalam berbagai macam bentuk representasi matematika.

Pada aspek-aspek dalam kemampuan pemahaman konsep matematis, siswa pada kelas discovery learning dengan pendekatan saintifik dilatih mengenal, mengklasifikasi, menyaji, dan mengaitkan berbagai konsep matematis melalui diskusi dengan teman-teman maupun dengan guru. Dengan demikian siswa berperan aktif selama pembelajaran dan membuat situasi be- lajar menjadi lebih kondusif dimana hal ini membantu siswa dalam proses mentalnya dan dalam menemukan suatu konsep dan menyelesaikan permasalahan matematika tentunya yang berkaitan dengan meningkatnya kemampuan pemahaman konsep matematis. Hal ini yang rupanya menjadikan siswa pada kelas pembelajaran discovery learning dengan pendekatan saintifik terbiasa untuk menerapkan konsep matematika dalam menyelesaikan soal yang berkaitan dengan kehidupan sehari-hari, mampu membedakan contoh dan bukan contoh dari suatu materi serta menyajikan konsep dalam berbagai bentuk representatif.

Dari hasil penelitian diperoleh bahwa penyebab peningkatan kemampuan pemahaman konsep matematis pada kelas dengan pembelajaran discovery learning dengan pendekatan saintifik lebih baik dari siswa dengan pembelajaran konvensional adalah perbedaan perlakuan pembelajaran. Namun terlepas dari lebih baiknya kelas pada pembelajaran discovery learning dengan pendekatan saintifik bukan berarti semua siswa pada kelas tersebut telah menguasai dengan baik kelima indikator kemampuan pemahaman konsep matematis, kualitas peningkatan kemampuan pemahaman konsep siswa dapat dilihat berdasarkan klasifikasi $N$-gain, nilai rata-rata $N$-gain pada kelas discovery learning dengan pendekatan saintifik dan kelas konvensional berturut-turut sebesar 0.78 berada pada klasifikasi sedang, dan 0.69 berada pada klasifikasi sedang. Sejalan dengan hal tersebut jika dilihat per indikator kemampuan pemahaman konsep, peningkatan kemampuan siswa kelas discovery learning dengan pendekatan saintifik lebih baik dari kelas konvensional walaupun pada indikator 2 (mengklasifikasikan objek menurut jenisnya berdasarkan sifat yang terdapat dalam materi) tidak berbeda secara signifikan, berturut-turut kelas discovery learning dan konvensional mampu mencapai skor rata-rata $\mathrm{N}$-Gain untuk indikator 2 sebesar 0.61 dan 0.53 . Kedua kelas berada pada klasifikasi sedang pada indikator tersebut dikarenakan siswa kedua kelas masih bingung dalam menentukan menggunakan rumus dalam memecahkan masalah.

Didapat peningkatan kemampuan pema- 
haman konsep matematis pada kelas discovery learning dengan pendekatan saintifik masih belum sesuai harapan. Penyebabnya diduga karena keterbatasan waktu penelitian yang hanya lima kali pertemuan kemudian juga pengakuan siswa yang belum terbiasa dengan soal-soal yang diberikan, berbeda dengan yang biasa diberikan oleh guru pada pembelajaran sebelumnya.

\section{B. Kemampuan Penalaran Matematis}

Hasil analisis diperoleh bahwa peningkatan kemampuan penalaran matematis siswa yang mendapatkan pembelajaran discovery learning dengan pendekatan saintifik lebih baik dari siswa yang memperoleh pembelajaran konvensional. Hail ini sejalan dengan penelitian sebelumnya (Hadi, 2015).

Penelitian pembelajaran discovery learning dengan pendekatan saintifik ini menggambarkan betapa pentingnya pembelajaran yang tidak langsung mengajak siswa menalar dan menyusun konsep permasalahan matematika. Selain itu pembelajaran discovery learning dengan pendekatan saintifik juga menekankan proses pembelajaran mulai dari stimulation (stimulasi/ pemberi rangsangan), problem statement (pernyataan/identifikasi masalah), data collection (pengumpulan data), data processing (pengolahan data), verification (pembuktian), generalization (menarik kesimpulan/generalisasi). Dengan demikian langkah dalam model ini sejalan dengan indikator kemampuan penalaran yang dijelaskan dalam teknis Peraturan Dirjen Dikdasmen Depdiknas nomor 506/C/Kep/PP/2004, diuraikan bahwa indikator siswa memiliki kemampuan penalaran adalah: (Yulia, 2012: 14) a) Kemampuan mengajukan dugaan, b) Kemampuan memeriksa kesahihan suatu argumen, c) Kemampuan memanipulasi matematika, menyusun bukti, memberikan alasan atau bukti terhadap kebenaran solusi, d) Kemampuan memanipulasi matematika, e) Kemampuan menarik kesimpulan. Namun terlepas dari lebih baiknya kelas pada pembelajaran discovery learning dengan pendekatan saintifik bukan berarti semua siswa pada kelas tersebut telah menguasai dengan baik kelima indikator kemampuan penalaran matematis, kualitas pe- ningkatan kemampuan penalaran matematis siswa dapat dilihat berdasarkan klasifikasi $\mathrm{N}$-gain, nilai rata-rata $N$-gain pada kelas discovery learning dengan pendekatan saintifik dan kelas konvensional berturut-turut sebesar 0,76 berada pada klasifikasi tinggi dan 0,69 berada pada klasifikasi sedang. Jika melihat nilai rata-rata $\mathrm{N}$-Gain secara keseluruhan, peningkatan kemampuan penalaran matematis kelas discovery learning dengan pendekatan saintifik lebih baik daripada kelas konvensional. Namun jika dilihat per indikator kemampuan penalaran matematis, peningkatan kemampuan siswa kelas konvensional untuk indikator 1 (mengajukan dugaan) memiliki ratarata paling tinggi dengan skor rata-rata 0.71 , dan dari kelas discovery learning dengan pendekatan saintifik mengalami peningkatan paling besar pada indikator 2 (memanipulasi matematika) dengan skor rata-rata 0.78 . Peningkatan kemampuan penalaran matematis masih dalam kategori tinggi. karena faktor waktu pada saat dilaksanakan posttest. Soal-soal kemampuan penalaran matematis berada pada nomor-nomor awal. Karena siswa kelas discovery learning dengan pendekatan saintifik dan kelas konvensional pada umumnya fokus pada soal-soal kemampuan pemahaman konsep yang berada pada nomor-nomor awal.

Dalam hubungan ini, proses pembelajaran discovery learning dengan pendekatan saintifik menekankan pada keaktifan siswa untuk mampu menalar dan mengkonstruksikan pengetahuan matematisnya sendiri. Dalam pembelajaran ini siswa melakukan diskusi kelompok dilanjut dengan diskusi kelas, saling berinteraksi, menyampaikan pendapat, bertanya, menanggapi pendapat orang lain, memeriksa kebenaran pendapat orang lain dan menarik kesimpulan atas apa yang telah didiskusikan.

Kegiatan-kegiatan inilah yang tampaknya menjadikan siswa pada kelas eksperimen terbiasa jeli dalam menentukan suatu kebenaran dari suatu pernyataan, mampu menyelidiki benar atau tidak suatu argument dan menyelesaikan permasalahan dengan model yang dikembangkan siswa sendiri. Sementara itu siswa pada kelas pembelajaran konvensional memiliki kesempatan yang kurang. Dari gambaran hasil ter- 
sebut diperoleh kesimpulan bahwa penyebab peningkatan kemampuan penalaran matematis pada kelas pembelajaran discovery learning dengan pendekatan saintifik lebih baik daripada kelas dengan pembelajaran konvensional adalah perbedaan perlakuan pembelajarannya. Namun terlepas dari pada lebih baiknya kelas dengan model pembelajaran discovery learning dengan pendekatan saintifik bukan berarti kelas tersebut telah menguasai dengan baik kemampuan penalaran matematis.

\section{Self Regulated Learning}

Menurut Zimmerman (1989) "Self Regulated Learning adalah kemampuan untuk menjadi partisipan yang aktif secara metagonitif, motivasi, dan perilaku (behavior) didalam proses belajar". Secara metakognisi, self regulated learning merencanakan, mengorganisasi, mengarahkan diri, memonitor diri, dan mengevaluasi diri pada tingkatan-tingkatan yang berbeda dari apa yang mereka pelajari. Sementara konsep Self Regulated Learning menurut (Bandura, 1977) dalam latar teori belajar siswa "Bahwa individu memiliki kemampuan mengontrol cara belajarnya dengan mengembangkan langkah-langkah observasi diri, menilai diri, dan memberi respon pada diri sendiri". Self Regulated Learning siswa ini menunjukkan seberapa besar usaha berpartisipasi dalam merencanakan, mengontrol dan mengatur tugas-tugas akademik, iklim dan struktur kelas. Mampu melakukan strategi disiplin yang bertujuan menghindari gangguan eksternal (lingkungan) dan internal (dalam diri), menjaga konsentrasi, usaha dan motivasi selama menyelesaikan tugas.

Ini menjelaskan bahwa Self Regulated Learning bukanlah sesuatu yang dibawa sejak lahir atau sesuatu dengan kualitas tetap dalam diri seseorang, tetapi merupakan proses kognitif, artinya Self Regulated Learning dapat ditingkatkan. Karena proses kognitif sering terjadi saat proses pembelajaran berlangsung, maka perkembangan Self Regulated Learning seseorang dapat ditingkatkan melalui kegiatan pembelajaran.

Dari pelaksanaan pembelajaran model dis- covery learning dengan pendekatan saintifik diperoleh hasil analisis self regulated learning lebih baik dibandingkan dengan self regulated learning pada kelas konvensional. Semua indikator rataan jawaban siswa menunjukan sikap positif pada pernyataan angket self regulated learning.

Penelitian dalam pembelajaran discovery learning dengan pendekatan saintifik ini tergambar dari hasil lembar observasi terhadap self regulated learning, peningkatan terlihat dari setiap pertemuan, namun pada pertemuan pertama dan kedua aktivitas siswa terhadap self regulated learning masih terlihat rendah dengan interprestasi sangat rendah, ini dikarenakan siswa belum mengerti materi yang disampaikan. Namun seiring berjalannya model discovery learning siswa mulai terbiasa aktif dalam pembelajaran, hasil observasi terhadap indikator self regulated learning mulai menunjukkan peningkatan yang signifikan. Di pertemuan ketiga, empat, dan kelima menunjukan rataan yang meningkat dengan interprestasi baik.

Kemudian Woolfolk, 2007 (Alhaddad, 2014) menyatakan bahwa "faktor-faktor yang mempengaruhiSRL meliputi pengetahuan (knowledge), motivasi (motivation) dan disiplin pribadi (selfdiscipline)". Ini sejalan dengan peran guru dalam Self Regulated Learning sebagai fasilitator dan moderator yang memberikan tanggung jawab kepada siswa untuk memperoleh sendiri konsep yang diperlukan dalam pembelajaran melalui interaksi dengan teman atau gurunya. Guru memberikan pandangan kepada siswa tentang rancangan pembelajaran, menarik rasa ingin tahun siswa pada permasalahan matematika dengan model pembelajaran dan tipe soal latihan yang dihubungkan dengan kehidupan sehari-hari, sehingga siswa termotivasi dan mandiri dalam menyelesaikan masalah matematika.

Demikian pula hal ini tergambar dari setiap jawaban siswa dalam hasil wawancara, banyak siswa yang awalnya belum terbiasa dengan iklim dan struktur pembelajaran discovery learning dengan pendekatan saintifik ini sehingga membuat siswa kebingungan dalam menentukan konsep dan menyelesaikan permasalahan matematika, dan karena beberapa kendala juga yang 
dialami siswa seperti kurangnya sarana belajar (buku paket matematika), membuat guru harus lebih ekstra membimbing siswanya agar mampu mencapai tujuan pembelajaran. Namun seiringnya perjalanan waktu siswa nampak senang dan terbiasa dengan model pembelajaran discovery learning dengan pendekatan saintifik, siswa senang belajar kelompok untuk menyelesaikan permasalahan, mencoba berbagai soal untuk mengasah kemampuan matematika, dan mengerjakan semua tugas dengan baik dan benar. Pola ini menggambarkan peningkatan self regulated learning siswa yang sejalan dengan teori Bandura (Sumarmo, 2004) bahwa "Self Regulated Learning adalah pengetahuan yang dimiliki seseorang tentang strategi belajar efektif yang digunakan untuk mencapai tujuan belajar dengan cara dan waktu yang tepat".

Berjalan dengan baiknya langkah-langkah diataslah yang akhirnya membuat siswa pada kelas pembelajaran discovery learning dengan pendekatan saintifik memiliki self regulated learning yang lebih baik dari siswa dengan pembelajaran konvensional.

\section{Hubungan Kemampuan Pemahaman Konsep dan Kemampuan Penalaran Matematis Siswa}

Berdasarkan analisis terdapat hubungan antara kemampuan pemahaman konsep dan penalaran matematis berada dalam kategori sedang dan bernilai positif yang mengidentifikasikan pola keduakemampuan tersebutsearahartinyasemakin tinggi peningkatan kemampuan pemahaman konsep maka semakin tinggi pula peningkatan kemampuan penalaran matematisnya, begitu juga sebaliknya. Hal ini terlihat dari data kedua kemampuan yang menunjukkan peningkatan yang searah pada setiap siswa.

Sedangkan menurut Bruner (dalam Jamawi, 2003:42) cara belajar yang baik bagi siswa untuk memahami konsep, dalil atau prinsip dalam matematika adalah dengan melakukan sendiri penyusunan representasi dan konsep, prinsip atau dalil tersebut. Proses membangun pemahaman inilah yang lebih penting dari pada hasil belajar, sebab pemahaman terhadap materi yang di- pelajari akan lebih bermakna apabila dilakukan sendiri. Sehingga model pembelajaran yang dapat menumbuh kembangkan pemahaman dan penalaran matematika adalah model pembelajaran dengan pendekatan penemuan keilmuan. Hal ini dikarenakan model pembelajaran penemuan merupakan suatu model pembelajaran yang progresif serta menitik beratkan kepada aktivitas siswa dalam belajar.

\section{E. Pengaruh Kemampuan Pemahaman Konsep dan Kemampuan Penalaran Matematis Terhadap Self Regulated \\ Learning}

Jika dilihat pada siswa kelas discovery learning dengan pendekatan saintifik pengaruh kemampuan pemahaman konsep, dan kemampuan penalaran matematis terhadap self regulated learning memiliki dampak yang berbeda.

Temuan penelitian menunjukkan bahwa peningkatan kemampuan pemahaman konsep memiliki pengaruh yang tidak signifikan terhadap self regulated learning berdasarkan pembelajaran yang diberikan. Terjadi pengaruh yang tidak searah antara kemampuan pemahaman konsep terhadap self regulated learning. Hal ini juga dapat dilihat dari hasil wawancara dengan beberapa siswa dapat diketahui bahwa sebagian besar dari mereka tidak terbiasa mengerjakan soal-soal yang menuntut pemahaman. Hal ini disebabkan pola pembelajaran lebih menekankan pada menghafal konsepkonsep yang dipelajari. Kebiasaan belajar dengan cara menghafal akan menyebabkan kemampuan berpikir sebatas lower order thinking (Holbrook, 2005: 1). Artinya jika siswa memiliki kemampuan pemahaman konsep yang bagus belum tentu memiliki self regulated learning yang baik.

Namun berbeda pada hasil peningkatan kemampuan penalaran matematis memiliki pengaruh yang signifikan terhadap self regulated learning. Terjadi hubungan positif dan pengaruh yang searah antara kemampuan penalaran matematis terhadap self regulated learning. Artinya jika siswa memiliki kemampuan penalaran matematis yang tinggi maka siswa memiliki self regulated learning yang baik. Besarnya pengaruh kemampuan penalaran matematis terhadap 
self regulated learning yaitu $42.3 \%$ sisanya diduga dipengaruhi oleh berdasarkan hasil wawancara adalah pemilihan strategi belajar siswa yang tepat dalam menangani setiap permasalahan matematika, kemudian pemilihan dari beberapa sumber belajar juga membuat siswa lebih mudah memecahkan permasalahan matematika, serta penerapan target belajar siswa ynag memungkinkan siswa memiliki self regulated learning yang baik. Ini sejalan dengan pendapat (Frederick, Blumenfeld, \& Paris, 2004) bahwa dalam bidang pendidikan self regulated learning telah memberikan pengaruh yang sangat signifikan khususnya untuk siswa SMP dan SMU. Dalam proses pembelajaran, siswa yang memiliki self regulated learning akan membangun tujuan belajar, mencoba memonitor, meregulasi, dan mengontrol kognisi, motivasi, dan perilakunya untuk mencapai tujuan pembelajaran.

\section{SIMPULAN}

Berdasarkan hasil penelitian dan pembahasan, maka penulis menarik kesimpulan sebagai berikut: Peningkatan kemampuan pemahaman konsep siswa yang mendapatkan pembelajaran discovery learning dengan pendekatan saintifik lebih baik dari pada siswa yang mendapat pembelajaran konvensional. Peningkatan kemampuan penalaran matematis siswa yang mendapatkan pembelajaran discovery learning dengan pendekatan saintifik lebih baik dari pada siswa yang mendapat pembelajaran konvensional. Self regulated learning siswa yang mendapatkan pembelajaran discovery learning dengan pendekatan saintifik lebih baik dari pada siswa yang mendapat pembelajaran konvensional. Gambaran self regulated learning siswa yang lebih baik dengan model pembelajaran discovery learning dengan pendekatan saintifik. Terdapat hubungan antara kemampuan pemahaman konsep matematis dan kemampuan penalaran matematis siswa yang memperoleh pembelajaran discovery learning dengan pendekatan saintifik. Terdapat pengaruh antara kemampuan pemahaman konsep dan kemampuan penalaran matematis terhadap self regulated learning.

\section{DAFTAR PUSTAKA}

Alhaddad, I. (2014). Peningkatan Kemampuan Komunikasi dan Pemecahan Masalah Serta Self Regulated Learning Mahasiswa Melalui Pembelajaran Model Toeffinger. Desertasi SPs UPI. Tidak Diterbitkan.

Aryani, K. (2010). Peningkatan Kemampuan Menulis dan Pemahaman Konsep Matematika melalui Pembelajaran dengan Strategi Writing From a Prompt dan Writing in Performance Tasks pada Siswa SMP. Tesis UPI Bandung. Tidak Diterbitkan.

Ballew, H. (1967). Discovery Learning and Critical Thinking in Alegbra. Alegbra.

Bandura, A. (1977). Social Learning Theory. Englewood Cliffs, NJ: Prentice-Hall

Beyer, B. K. (1991). Teaching Thinking Skill: A Handbook for Elementary School Teachers. New York, USA: Allyn \& Bacon.

Dasari, D. (2002). Pengembangan Pembelajaran Matematika Berdasarkan Kurikulum Berbasis Kompetensi. Bandung: JICA IMSTEP FPMIPA UPI.

Fredericks, J. A., Blumenfeld, P.C., \& Paris, A.H. (2004). School engagement: potential of the concept, state of the evidence. Review of Educational Research. 74, 59-109.

Holbrook. (2005). Making Chemistry Teaching Relevant. Journal Chemical Education International 6, 1 [online] http://www.iupac.org/ publications/cei. Diakses tanggal 20 Juni 2014.

Houston, W. Robert., et all. (1988). Touch the Future Teach. St. Paul, MN: West Publishing Company.

Indrawan, Y. (2014). Metodologi Penelitian Kuantitatif, Kualitatif, dan Campuran untuk Manajemen, Pembangunan, dan Pendidikan. Bandung: Refika Aditama.

Jarnawi. (2003). Meningkatkan Kemampuan Penalaran Dan Pemahaman Matematika Siswa Sekolah Lanjutan Tingkat Pertama Melalui Pendekatan PembelajaranOpen-Ended, Studi Eksperimen Pada Siswa Sekolah Lanjutan Pertama Negeri Di Kota Bandung. Disertasi tidak diterbitkan. Bandung: Program Pascasarjana UPI Bandung. 
Juandi, D. (2008). Pembuktian, Penalaran, dan Komunikasi Matematik. [online]. Tersedia : http://file.upi.edu/Direktori/FPMIPA/JUR. PEND.MATEMA

Kartono, Sumarmi. (2015). Analisis Kemampuan Komunikasi Matematis Siswa SMP Kelas VIII SMP Pada Model Pembelajaran TSTS Dengan Pendekatan Scientific. Unnes Journal of Mathematics Education. 4(2): 1-7. [online]. Tersedia: http://jurnal.unnes.ac.id/sju/index. php/ujme.

Kemendikbud. (2013). Model Pengembangan Penilaian Hasil Belajar. Jakarta: Direktorat Pembinaan SMA

Kementerian Pendidikan dan Kebudayaan. (2014). Peraturan Menteri Pendidikan dan Kebudayaan Republik Indonesia nomor 103 tentang Kurikulum 2013 Sekolah Menengah Atas/Madrasah Aliyah

Killpatrick, J., Swafford, J., \& Findell, B. (Eds). (2001). Adding It Up : Helping Children Learn Mathematics. Washington, DC : National Academy Press.

Latifah, E. (2010). Strategi Self Regulated Learning dan Prestasi Belajar: Kajian Meta Analisis. Journal Psikologi 37(1) 110-129.

Lohman, D.F \& Lakin, J.M. (2009). Reason and Intelligence. [online]. Tersedia: http:// faculty.education.uiowa.edu/dlohman/pdf/ Reasoning\%20and\%20Intell_Lohman\%20 102709.pdf. [5 Oktober 2012]

Machin, A. (2014). Implementasi Pendekatan Saintifik, Pemahaman Karakter, dan Konservasi Pada Pembelajaran Materi Pertumbuhan. Jurnal Pendidikan IPA Indonesia, volume 3(1): 28-35.

Nasution, S. L. (2011). Pembelajaran Matematika melalui pendekatan Metakognitif dengan Model Advance Organizer untuk Meningkatkan Kemampuan Pemahaman dan Penalaran Matematis Siswa Sekolah Menengah Pertama: Suatu Studi Eksperimen pada Salah Satu SMP Negeri di Jakarta. Tesis Program Pascasarjana UPI Bandung: tidak diterbitkan.

National Council of Teacher of Mathematics. (2000). Principles and Standards for School Mathematics. Reston, VA : NCTM
Nur, M. (1998). Proses Belajar Mengajar Dengan Metode Pendekatan Keterampilan Proses. SIC. Surabaya.

Pintrich, P. R. dan De Groot, (1990) "Motivational and Self-regulated learning Component of Classroom Acedemic Performance", Journal of Educational Psychology, (82, 1), hlm. 33-40.

Pollatsek, A., Lima S. dan Well A.D. (1981). "Concept or Computation: Student's Understanding of the Mean". Education Studies in Mathematics, vol.12, No.2, pp. 191-204

Ruseffendi, E. T. (2010). Dasar - Dasar Penelitian Pendidikan dan Bidang Non Eksakta Lainnya. Bandung: Tarsito.

Santrock, J.W. (2007). Psikologi Pendidikan. Jakarta: Kencana Prenada Media Group.

Schunk, D. H. dan Zimmerman, B. J. Self-regulated Learning: From Teaching to Self-Reflective Prctice (New York: The Guilford Press, 1998), hlm.viii

Seifert, K. (2012). Pedoman Pembelajaran \& Instruksi Pendidikan. Yogyakarta: IRCiSoD.

Semiawan, C. (1992). Pendekatan Keterampilan Proses. Gramedia. Jakarta.

Schunk, D. H. dan Zimmerman, B. J. Self-regulated Learning: From Teaching to Self-Reflective Prctice (New York: The Guilford Press, 1998), hlm.viii

Sugiyono, (2011). Metode Penelitian Pendidikan (Pendekatan Kuantitatif, Kualitatif, dan $R \nLeftarrow D)$, Bandung: Alfabeta.

Suherman, dkk. (2001). Common TexBook Strategi Pembelajaran Matematika Kontemporer. Bandung: Jurusan Pendidikan Matematika UPI Bandung.

Suherman, E. (2003). Evaluasi Pembelajaran Matematika. Bandung: JICA UPI.

Sumarmo, U. (1987). Kemampuan Pemahaman dan Penalaran Matematika Siswa SMA Dikaitkan dengan Kemampuan Penalaran Logika Siswa dan Beberapa Unsur Proses Belajar Mengajar. Disertasi pada sekolah Pasca Sarjana UPI : Tidak Diterbitkan.

Sumarmo, U (2004) Kemandirian Belajar. Apa, Mengapa, dan Bagaimana Dikembangkan Pada Peserta Didik pada seminar Pendidikan Matematika dijurusan pendidikan FMIPA 
Universitas Negeri Yogyakarta, tanggal 8 juli 2004. Tidak diterbitkan.

Sumarmo, U. (2010). Berpikir dan Disposisi Matematika: Apa, Mengapa, dan Bagaimana dikembangkan pada Peserta Didik. FPMIPA UPI. [online]. Tersedia: http://dc356.4shared. com/doc/ourBAi09/preview.html. novermber 2012]

Suryadi, D. (2012). Membangun Budaya Baru dalam Berpikir Matematika. Bandung: Rizqi Press

Turmudi. (2009). Taktik dan Strategi Pembelajaran Matematika (Referensi Untuk Guru SMK,
Mahasiswa, dan Umum). Jakarta Pusat: PT. Leuser Cita Pustaka

Yulia, W. (2012). Implementasi Pembelajaran Matematika dengan Pendekatan Investigasi dalam Meningkatkan Kemampuan Penalaran Matematis Siswa SMP. Skripsi UPI Bandung: Tidak diterbitkan.

Zulfa, F. Yerizon. Amalita (2014) "Pengaruh Penerapan Metode Penemuan Terbimbing Terhadap Kemampuan Penalaran Matematis Siswa Kelas XI IPA SMAN 1 Padang Panjang”. Jurnal Pendidikan Matematika. (3, 3,). hal $1-4$. 